\title{
A Personal Story of My Work on Scientific Literacy Through My Traditional Islamic Perspective
}

\section{Adib Rifqi Setiawan}

Research is worthwhile only when the outcome is uncertain. Once we know the answer, no matter how interesting, it's no longer research. It is a statement that I can conclude through my experiences when I was advisee of Setiya Utari. Our personal dialogue is so important, that stimulating me to develop my own academic-style, especially affecting my research interest in scientific literacy. Setiya Utari has suggested me to work on scientific literacy, of whom I had not heard, on 4 February 2015 when she said that. The suggestion, however, great choice for me to focus on this work for a long time. I like scientific literacy because it shows that individuals rewarded not for what they know, but for what they can do with what they know. It is linear, in my opinion, with my traditional islamic perspective based on quotation of Hujjat alIslām Abū Ḥāmid Muhammad ibn Muhammad al-Ghozālīin in Ayyuhā al-Walad (Arab: أيها الولد):

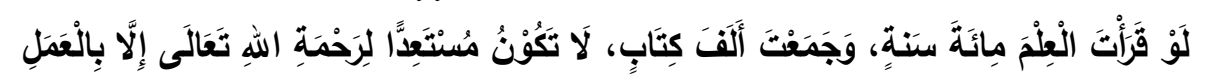

"Even if you studied for a hundred years and collected a thousand books, you would not eligible for the mercy of God the Exalted except through action."

I feel as Islamic people, the worth of scientic literacy is as we can find this verse in al-Qur'ān:

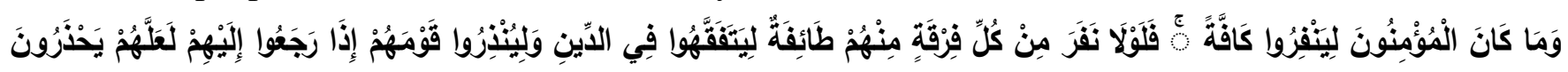

that interpreted by Jalāl al-Dīn Abū al-Faḍl 'Abd al-Raḥmān ibn Abī Bakr al-Suyūṭ̂̀ in his co-work Tafsīr alJalālayn (Arabic: تفسير الجلالين):

"When the Prophet Muhammad was about to dispatch a raiding party — after they [certain Muslims] had been reproached for staying behind - all of them went forth, and so the following was revealed: It is not for the believers to go forth, on a raid, altogether: why should not a party, a group, of every section, of every tribe, of them go forth, while the others remain behind, so that they, those who remain behind, may become learned in religion and that they may warn their folk when they return to them, from the raid, by teaching them some of the rulings which they have come to learn, so that they may beware? of God's punishment, by adhering to His commands and prohibitions. Ibn 'Abbās said that this [verse] is specifically [intended] for raiding parties, while the previous one is [specifically] to prohibit any individual staying behind when the Prophet (s) sets out [on a campaign]."

Since then, I work on scientific literacy in various context, i.e. biology learning, Islamic studies, nor primary education as well. 